Article

\title{
The FT-IR and Raman Spectroscopies as Tools for Biofilm Characterization Created by Cariogenic Streptococci
}

\author{
Barbara Gieroba $^{1}{ }^{(}$, Mikolaj Krysa $^{1}$, Kinga Wojtowicz $^{1}$, Adrian Wiater ${ }^{2}{ }^{(}$, \\ Małgorzata Pleszczyńska ${ }^{2}$, Michał Tomczyk ${ }^{3}$ (D) and Anna Sroka-Bartnicka 1,4,*(D) \\ 1 Department of Biopharmacy, Medical University of Lublin, Chodzki 4a, 20-093 Lublin, Poland; \\ barbaragieroba@umlub.pl (B.G.); krysamikolaj@gmail.com (M.K.); kingaewawojtowicz@gmail.com (K.W.) \\ 2 Department of Industrial and Environmental Microbiology, Institute of Biological Sciences, \\ Maria Curie-Skłodowska University, Akademicka 19, 20-033 Lublin, Poland; \\ adrianw2@poczta.umcs.lublin.pl (A.W.); m.pleszczynska@poczta.umcs.lublin.pl (M.P.) \\ 3 Department of Pharmacognosy, Faculty of Pharmacy, Medical University of Białystok, ul. Mickiewicza 2a, \\ 15-230 Białystok, Poland; michal.tomczyk@umb.edu.pl \\ 4 Department of Genetics and Microbiology, Maria Curie-Skłodowska University, Akademicka 19, \\ 20-033 Lublin, Poland \\ * Correspondence: anna.sroka@umlub.pl or annasroka@tlen.pl; Tel.: +48-81448-7225
}

Received: 8 May 2020; Accepted: 25 May 2020; Published: 27 May 2020

check for updates

\begin{abstract}
Fourier transform infrared (FT-IR) and Raman spectroscopy and mapping were applied to the analysis of biofilms produced by bacteria of the genus Streptococcus. Bacterial biofilm, also called dental plaque, is the main cause of periodontal disease and tooth decay. It consists of a complex microbial community embedded in an extracellular matrix composed of highly hydrated extracellular polymeric substances and is a combination of salivary and bacterial proteins, lipids, polysaccharides, nucleic acids, and inorganic ions. This study confirms the value of Raman and FT-IR spectroscopies in biology, medicine, and pharmacy as effective tools for bacterial product characterization.
\end{abstract}

Keywords: bacterial polysaccharides; FT-IR microspectroscopy; Raman spectroscopy; biofilms; dental caries; bacteria; mutans streptococci

\section{Introduction}

Dental caries is an infectious disease associated with the accumulation of bacterial plaque on the tooth surface [1]. Dental plaque, the biofilm formed on the tooth surface, consists of a complex microbial community (less than $10 \%$ of biofilm dry weight) embedded in a bacterial and salivary-origin matrix of highly hydrated extracellular polymeric substances (EPS, more than $90 \%$ of biofilm dry weight). Dental plaque formation is a multistep process, which involves acquired pellicle formation, initial sucrose-independent and subsequent polysaccharide-mediated attachment of cells to the tooth surface, biofilm maturation, and dispersion of biofilm cells [2]. Mutans streptococci (MS, mainly Streptococcus mutans and S. sobrinus) have been isolated from human dental plaque and have been implicated as a primary causative agent of dental caries [3]. Adhesion, acidogenicity, and acid tolerance are the main virulence factors of the bacteria. MS secrete constitutive glucosyltransferases (Gtfs) that cooperatively synthesize polysaccharide components of EPS from ingested sucrose. S. mutans produce three glucosyltransferases. GtfD synthesizes water-soluble $(1 \rightarrow 6)-\alpha$-D-glucans (its activity is primer-dependent), GtfB and GtfC synthesize water-insoluble $(1 \rightarrow 3)-\alpha$-D-glucans, and the second produces a mixture of water-soluble and water-insoluble glucans, respectively [4-6]. It has been found that simultaneous synthesis of glucans by GtfB and GtfC is essential for formation of high-density 
biofilm with high adhesion, which promotes their binding to an apatite surface [7]. S. sobrinus strains extracellularly produce at least four kinds of Gtfs: $(1 \rightarrow 3)-\alpha$-D-glucan synthase (GtfI) and $(1 \rightarrow 6)$ - $\alpha$-D-glucan synthase (GtfU), ( $1 \rightarrow 6)$ - $\alpha$-D-glucan synthase (GtfT), and an oligo-isomaltosaccharide synthase (GtfS) [8]. Glucosyltransferases and their polysaccharide products have been shown to be fundamental virulence factors in the pathogenesis of dental caries because they are responsible for close adhesion to the tooth surface in the presence of sucrose. Additional virulence factors of mutans streptococci are glucan-binding proteins (Gbps). S. mutans produces at least four Gbps: GbpA, GbpB, $\mathrm{GbpC}$, and $\mathrm{GbpD}$. The importance of these proteins is to maintain biofilm architecture by linking bacteria and extracellular molecules of glucan [9]. Another factor that is associated with the virulence of $S$. mutans is the cell surface protein antigen c (PAc). PAc participates in sucrose-independent bacterial adherence to the tooth surface via interaction with the salivary pellicle [7].

Fourier transform infrared (FT-IR) and Raman spectroscopies are powerful techniques for generating direct information about the molecular and chemical composition of biological samples [10-12]. Compared with conventional histological and/or microscopic methods, the microspectroscopic approach is considered advantageous because it is fast, non-invasive, staining- and labeling-free, and less susceptible to human subjective analysis. The combination of these complementary spectroscopic techniques can offer a more comprehensive approach to the analysis of intact samples and ensures more detailed chemical information [13]. The coupling of FT-IR or Raman vibrational spectrometers with a microscope can provide useful information on molecular differences and spatial distributions within and between various healthy and pathological cells and tissues at a microscopic level [13-15]. A recent Raman spectroscopic study on bacterial biofilms demonstrated that this technique enables the identification and analysis of nucleic acids, carbohydrates, proteins, and extracellular polymeric substances in biofilms created by a Pseudomonas sp. strain [16]. It has also been applied to characterization of the typology and matrix composition of biofilm produced by Pseudoalteromonas haloplanktis TAC125 in the context of environmental and cold adaptation [17]. In the field of dentistry, it can be used to assess the mineral properties of calcified tissue [18], examine the hydroxyapatite single crystallites [19], compare dental tissues, including enamel and dentin [20], and characterize hydroxylated phosphates [21]. It can also be applied to dental material research, [22,23] and finally utilized for tooth caries diagnosis [24,25].

The aim of the present study was to investigate the composition (the molecular structure and distribution of particular chemical components) of bacterial biofilms produced by various cariogenic strains of Streptococcus spp. with the use of FT-IR and Raman spectroscopic imaging. This vibrational spectroscopic approach proves to be useful in determining the structure of biological samples, which could potentially reduce the cost of experiments and shorten the time of analysis.

\section{Results}

\subsection{FT-IR Spectroscopy}

The relative intensity and FT-IR spectra normalized to the Amide I band of the studied biofilm samples are presented in Figures 1 and 2, respectively. A closer look at the regions of lipids, proteins, and carbohydrates shows the relative intensity of the FT-IR spectra, as shown in Figure 3. 


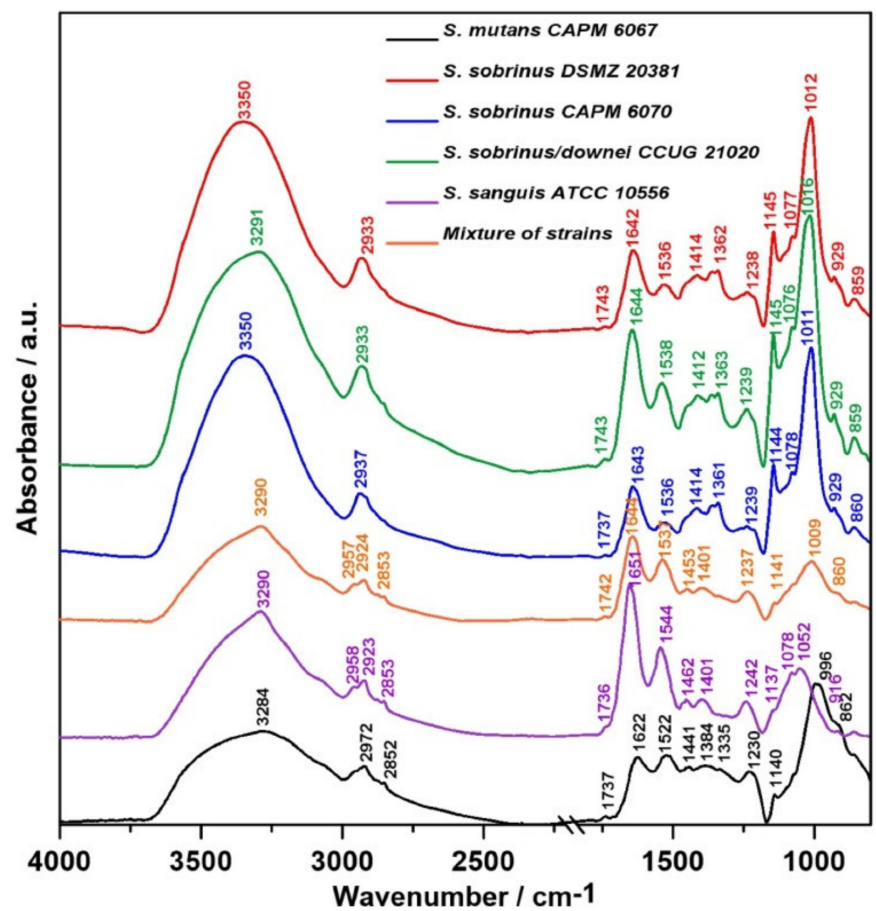

Figure 1. Representative relative intensity of Fourier transform infrared (FT-IR) spectra of bacterial biofilms.

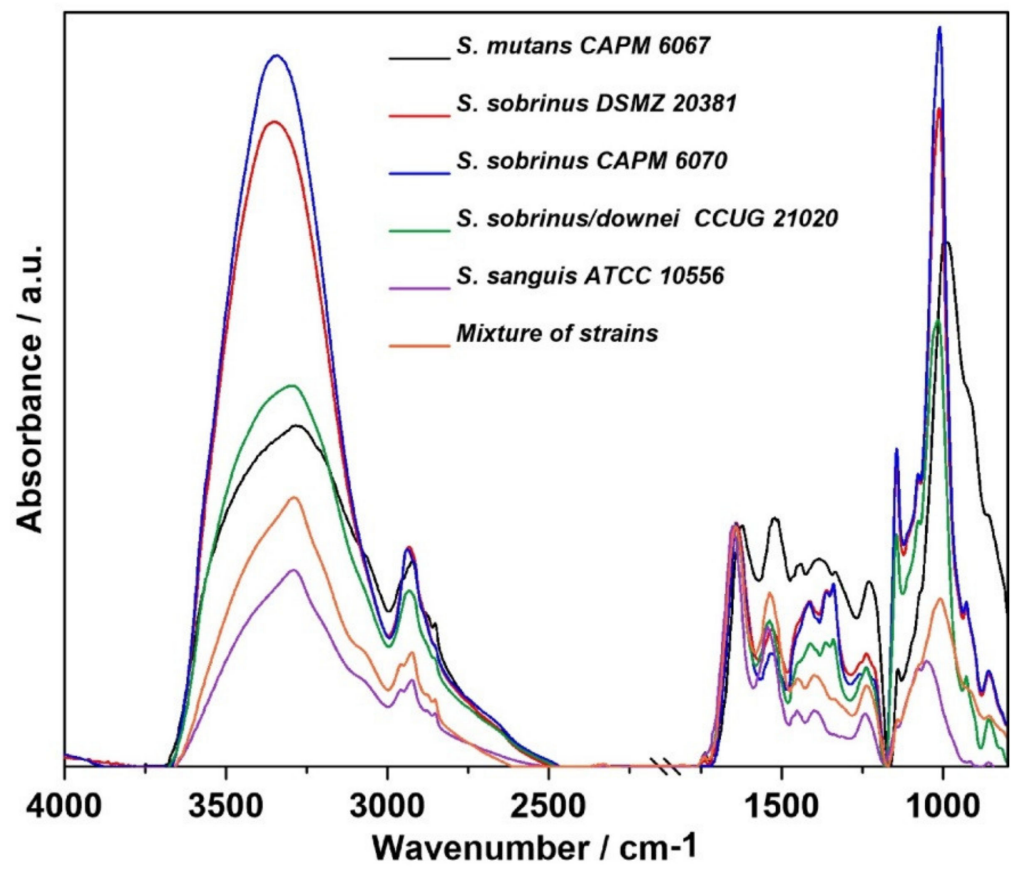

Figure 2. The FT-IR spectra of bacterial biofilms normalized to the Amide I band. 

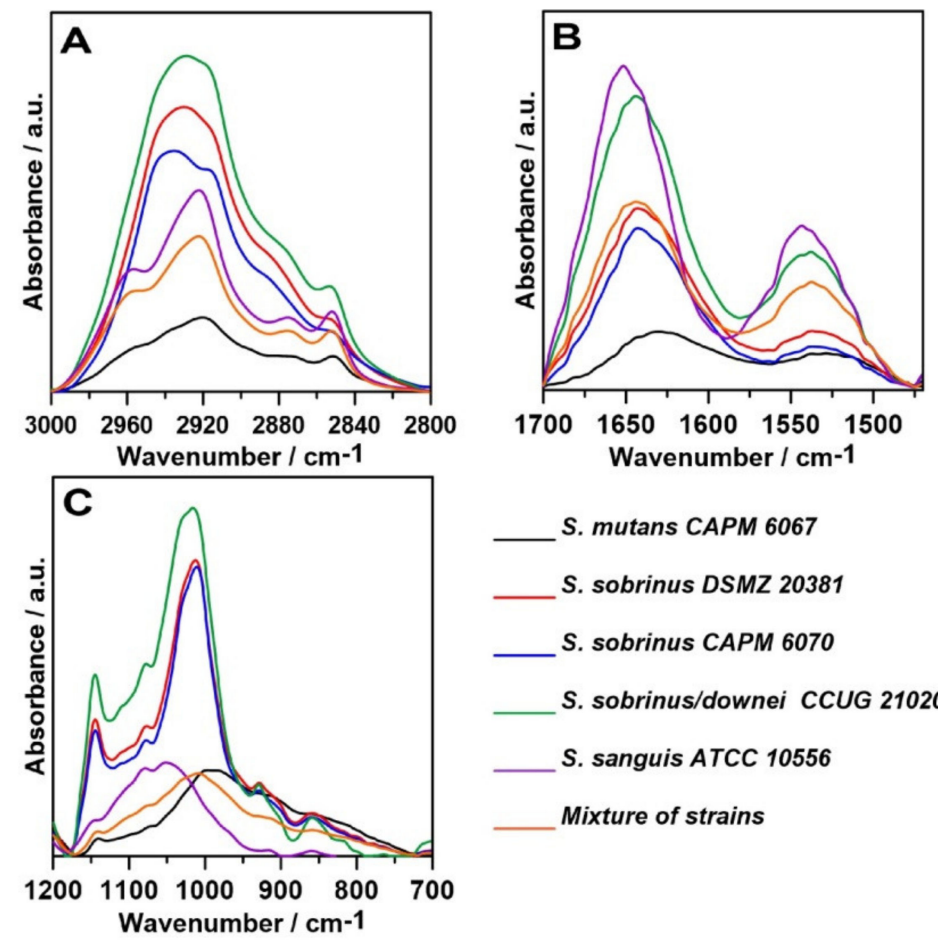

S. mutans CAPM 6067

S. sobrinus DSMZ 20381

S. sobrinus CAPM 6070

S. sobrinus/downei CCUG 21020

S. sanguis ATCC 10556

Mixture of strains

Figure 3. The relative intensity of FT-IR spectra of the fingerprints regions of: (A)-lipid region $\left(3000-2800 \mathrm{~cm}^{-1}\right),\left(\right.$ B) - Amides I and II region (1700-1470 $\left.\mathrm{cm}^{-1}\right)$, and (C) - carbohydrate region $\left(1200-700 \mathrm{~cm}^{-1}\right)$.

The main changes between the samples have been shown in the protein, lipid, and sugar regions of averaged spectra, as shown in Figure 1, and normalized spectra, as presented in Figure 2. Table 1 summarizes the characteristic wavenumbers together with the proposed vibrational modes ascribed to functional groups in individual biofilm components [26-37]. The broad band at $3200-3350 \mathrm{~cm}^{-1}$ corresponds to Amide A [26] with strong absorbance intensity. Naumann et al. divided spectra acquired from bacterial samples into five so-called windows of vibration groups $[27,38]$. The spectral region of 3000-2800 $\mathrm{cm}^{-1}$ (Figure 3A) is assigned to symmetric and asymmetric vibrations of $\mathrm{C}-\mathrm{H}$ in the $-\mathrm{CH}_{2}$ and $-\mathrm{CH}_{3}$ methylene groups, which are characteristic for lipids concentrated in bacterial cell walls and membranes [39]. The highest intensity of this band was detected for S. sobrinus/downei CCUG 21020 and the lowest for S. mutans CAPM 6067. The magnitude of these alterations may depend on the hydrocarbon chain length and chemical structure of the polar head group of the membrane lipids [40].

The Amide I and Amide II bands are susceptible to changes in the secondary structures of proteins [41]. Absorbance bands characteristic for Amide I and Amide II (Figure 3B, 1500-1700 $\mathrm{cm}^{-1}$ ) are relatively higher in S. sanguis ATCC 10556 and S. sobrinus/downei CCUG 21020 compared to other studied groups, and are the lowest in S. mutans CAPM 6067. Only small, inconsiderable shifts were observed in Amide I (1642-1651 cm $\left.\mathrm{cm}^{-1}\right)$ and Amide II bands $\left(1536-1544 \mathrm{~cm}^{-1}\right)$ in all spectra, except in S. mutans CAPM $6067\left(1622 \mathrm{~cm}^{-1}\right.$ and $1522 \mathrm{~cm}^{-1}$, respectively). It is worth to remember that in FT-IR measurements, water can distort the results, contributing to the Amide A and Amide I bands. Though bacterial biofilms have different densities, the overlapping of water may vary, reducing the analytical value of FT-IR spectroscopy in this case. Therefore, the results should be interpreted with caution [42]. 
Table 1. The most significant bands obtained in the type of FT-IR vibration with particular assigned components. Spectra of biofilm samples and the types of vibrations with particular assigned components.

\begin{tabular}{|c|c|}
\hline Wavenumber $\left(\mathrm{cm}^{-1}\right)$ & Assignment and the Type of Vibration * \\
\hline $3200-3350$ & $v(\mathrm{~N}-\mathrm{H}), v(\mathrm{O}-\mathrm{H})$, Amide $\mathrm{A}$, water \\
\hline $2950-2960$ & $v_{\text {as }}\left(\mathrm{CH}_{3}\right)$, lipids \\
\hline $2920-2940$ & $v_{\text {as }}\left(\mathrm{CH}_{2}\right)$, lipids \\
\hline $2850-2860$ & $v_{\mathrm{s}}\left(\mathrm{CH}_{2}\right)$, lipids \\
\hline $1730-1740$ & $v(\mathrm{C}=\mathrm{O})$, phospholipids \\
\hline $1700-1600$ & $80 \% \vee(\mathrm{C}=\mathrm{O}), 20 \% \vee(\mathrm{C}-\mathrm{N}), \tau(\mathrm{HOH})$, Amide I, water \\
\hline $1600-1500$ & $60 \% \tau(\mathrm{N}-\mathrm{H}), 30 \% \vee(\mathrm{C}-\mathrm{N}), 10 \% \vee(\mathrm{C}-\mathrm{C})$, Amide II \\
\hline $1441-1462$ & pyrrolidine ring vibration of proline and hydroxyproline \\
\hline $1450-1400$ & $\delta_{\text {as }}\left(\mathrm{CH}_{3}\right), \delta_{\text {as }}\left(\mathrm{CH}_{2}\right)$, proteins, lipids \\
\hline $1400-1350$ & $\delta_{\mathrm{s}}\left(\mathrm{CH}_{3}\right), \delta_{\mathrm{s}}\left(\mathrm{CH}_{2}\right), v_{\mathrm{s}}(\mathrm{C}=\mathrm{O})$, proteins, lipids \\
\hline $1350-1200$ & $\tau(\mathrm{N}-\mathrm{H}), v(\mathrm{C}-\mathrm{N}), \tau(\mathrm{C}=\mathrm{O}), v(\mathrm{C}-\mathrm{C}), v\left(\mathrm{CH}_{3}\right)$, Amide III, \\
\hline $1242-1230$ & $v_{\text {as }}\left(\mathrm{PO}_{2}^{-}\right)$, DNA, RNA, phospholipids, phosphorylated proteins \\
\hline $1144-1137$ & Oligosaccharydes \\
\hline$\sim 1086$ & $v_{\mathrm{s}}\left(\mathrm{PO}_{2}^{-}\right), \mathrm{DNA}, \mathrm{RNA}$, phospholipids, phosphorylated proteins \\
\hline $1080-1070$ & $v(\mathrm{C}-\mathrm{C}), \beta$-glucan bonds \\
\hline 1046-999 & Skeletal vibration connected to anomeric structure of D-glucose \\
\hline $1009-1016$ & $v(\mathrm{C}-\mathrm{C}), \mathrm{RNA}$, ribose \\
\hline$\sim 972$ & $v(\mathrm{C}-\mathrm{C}), v(\mathrm{C}-\mathrm{O}), \mathrm{DNA}$, deoxirobose \\
\hline $900-700$ & anomeric ring vibrations for tryptophan, tyrosine, and phenyloalanine \\
\hline 929 & $(1 \rightarrow 3)$ - $\alpha$-D-glucan \\
\hline $860-852$ & $(1 \rightarrow 3),(1 \rightarrow 6)-\alpha$-D-glucan \\
\hline
\end{tabular}

* Types of vibrations: stretching $(v)$, deformational $(\delta)$, bending $(\tau)$, symmetrical $(s)$, and asymmetrical (as) modes.

The "sugar region" (Figure 3C), according to Naumann et al. [38] $\left(1200-950 \mathrm{~cm}^{-1}\right)$, is a spectral region that is important for the structural characterization of polysaccharides with the $1137-1144 \mathrm{~cm}^{-1}$ band, indicating the presence of oligosaccharides in all tested samples [34,36]. In S. sobrinus DSMZ 20381, S. sobrinus CAPM 6070, and S. sobrinus/downei CCUG 21020 samples, there is band at 1009-1016 $\mathrm{cm}^{-1}$ with a shoulder at 1076,1077, and $1078 \mathrm{~cm}^{-1}$ assigned to $\beta$-glucan bonds $[37,43]$. The shoulder band at $1078 \mathrm{~cm}^{-1}$ also appeared in the S. sanguis ATCC 10556 sample. Moreover, the band characteristic for the common bacterial polysaccharide $-(1 \rightarrow 3),(1 \rightarrow 6)-\alpha$-D-glucan $\left(852-860 \mathrm{~cm}^{-1}\right.$ range) is located in the "anomeric region" (950-700 $\left.\mathrm{cm}^{-1}\right)$ [37]. The latter region $\left(1180-960 \mathrm{~cm}^{-1}\right)$ contains weak bands that are sensitive to D-glucose [44]. In the tested samples, the highest intensity for glucose is in the range $999-1046 \mathrm{~cm}^{-1}$. The band at $929 \mathrm{~cm}^{-1}$ corresponds to $(1 \rightarrow 3)-\alpha-\mathrm{D}$-glucan [43]. It is worth to remember that carbohydrates, phosphates/phospholipids, and nucleic acids have overlapping biological signals (the wavenumber region 1300-900 $\mathrm{cm}^{-1}$ ) in the mid-infrared (IR) [35].

Next, the second-order derivatives were determined in three analyzed spectral regions (Figure 4). The aim of this operation was to study the molecular modifications of lipids, carbohydrates, and secondary structures of proteins in the tested biofilms.

The second-order derivative in the $3000-2800 \mathrm{~cm}^{-1}$ spectral range (Figure $4 \mathrm{~A}$ ) shows slight differences in the lipid profiles of the samples. The most pronounced variation is the $\sim 2920 \mathrm{~cm}^{-1}$ shifts, which correspond to the stretching asymmetrical vibration of $\mathrm{CH}_{2}$ groups [45]. This suggests different lipid compositions of bacterial membranes in the analyzed strains. 

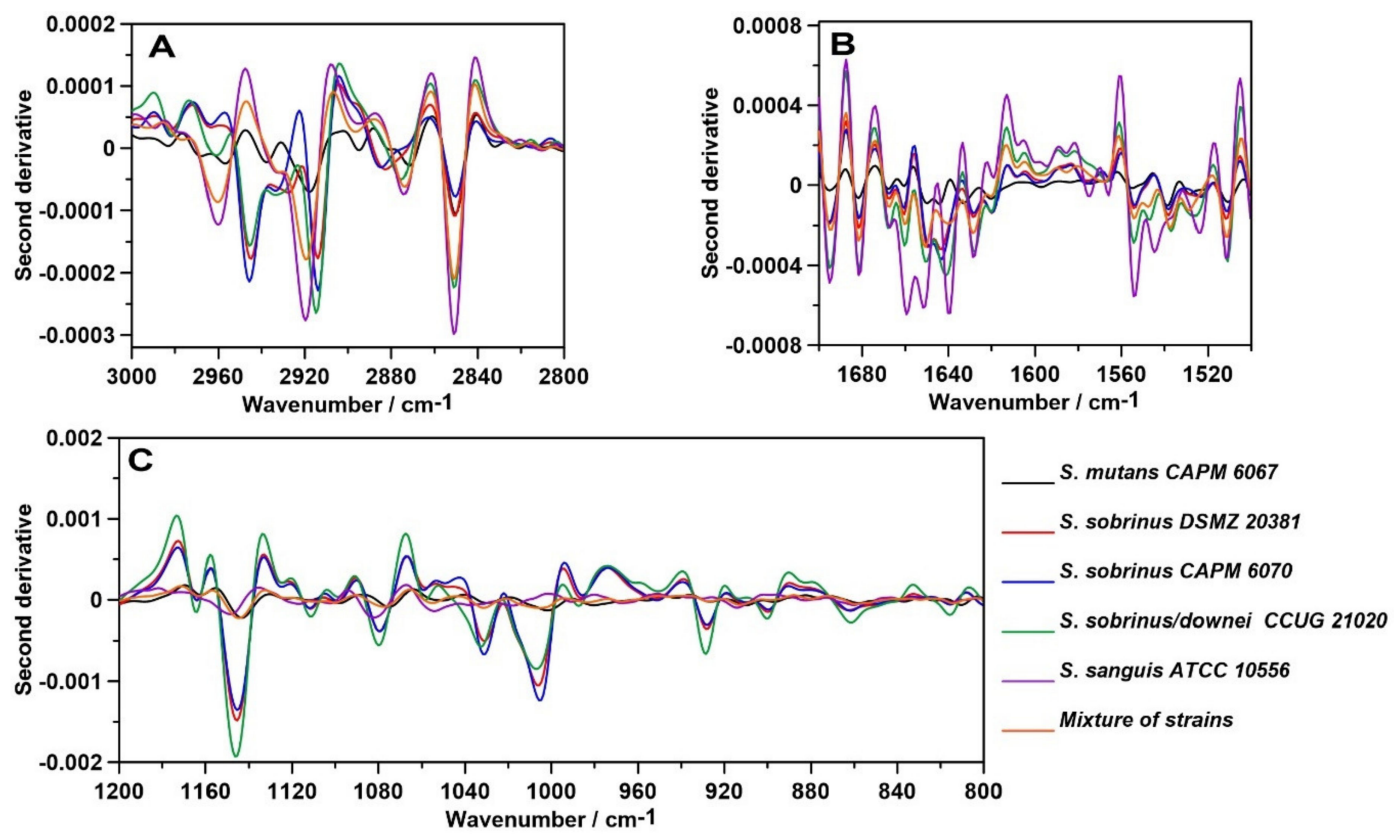

Figure 4. The second-order derivatives of the FT-IR spectra of biofilms; (A)-lipid region; (B)_protein region; (C)—carbohydrate region.

The greatest similarity shows the course of the second derivative determined for Amide bands (Figure 4B). Only in the case of S. sanguis ATCC 10556, additional minima of the second derivative in $1648-1660 \mathrm{~cm}^{-1}$ assigned to $\alpha$-helices and $1639 \mathrm{~cm}^{-1}$ corresponding to a parallel $\beta$-sheet secondary structure of proteins [46] were detected. This strain may produce adjective proteins contributing to biofilm adhesion and architecture or bacterial virulence.

The course of the second derivative function in terms of sugars (Figure 4C) indicates similarity in the carbohydrate composition of biofilms produced by the $S$. sobrinus DSMZ 20381, S. sobrinus CAPM 6070, and S. sobrinus/downei CCUG 21020 strains. Similarities in the polysaccharide region were also observed in S. mutans CAPM 6067, S. sanguis ATCC 10556, and mixes of strains. This indicates different carbohydrate profiles of the studied bacterial biofilms.

\subsection{FT-IR Imaging}

Our next analysis was the spectroscopic mapping of the distribution of proteins and sugars in the biofilm samples. We did not examine the lipid region due to its smaller contribution in plaque adhesion, dispersion, and virulence potential. The results are presented in Figure 5.

The visualization (Figure 5) shows the spatial distribution and intensity of absorption of two important biofilm compounds $((1 \rightarrow 3)-\alpha$-D-glucan and Amide I) in the $x-y$ axis of the sample images. A magnified picture of each sample was taken prior to analysis and represented the differential structures of selected protein and carbohydrate bands. The presence of the bands, which are assigned to the $(1 \rightarrow 3)-\alpha$-D-glucan and Amide I (at $980-900 \mathrm{~cm}^{-1}$ and $1700-1600 \mathrm{~cm}^{-1}$, respectively), is visible in all samples, and confirms that they are characteristic biofilm components. The main visible difference between the chemical images is the lower absorbance intensity of the $(1 \rightarrow 3)-\alpha-\mathrm{D}$-glucan bands in the S. sobrinus DSMZ 20381 and strain mixture samples. Regarding the Amide I band, the highest absorbance intensity is shown by the $S$. sanguis ATCC 10556 sample. The differences in intensity result from the various quantitative contents of the above-mentioned compounds in the studied bacterial biofilms. They are composed of various qualitative and quantitative sugar and protein constituents, which, in diversified ways, contribute to plaque formation and consequently influence the potential for dental caries progression. This may mean that each strain of bacteria creates a different type of biofilm, including in terms of density and the grade of adhesion. 

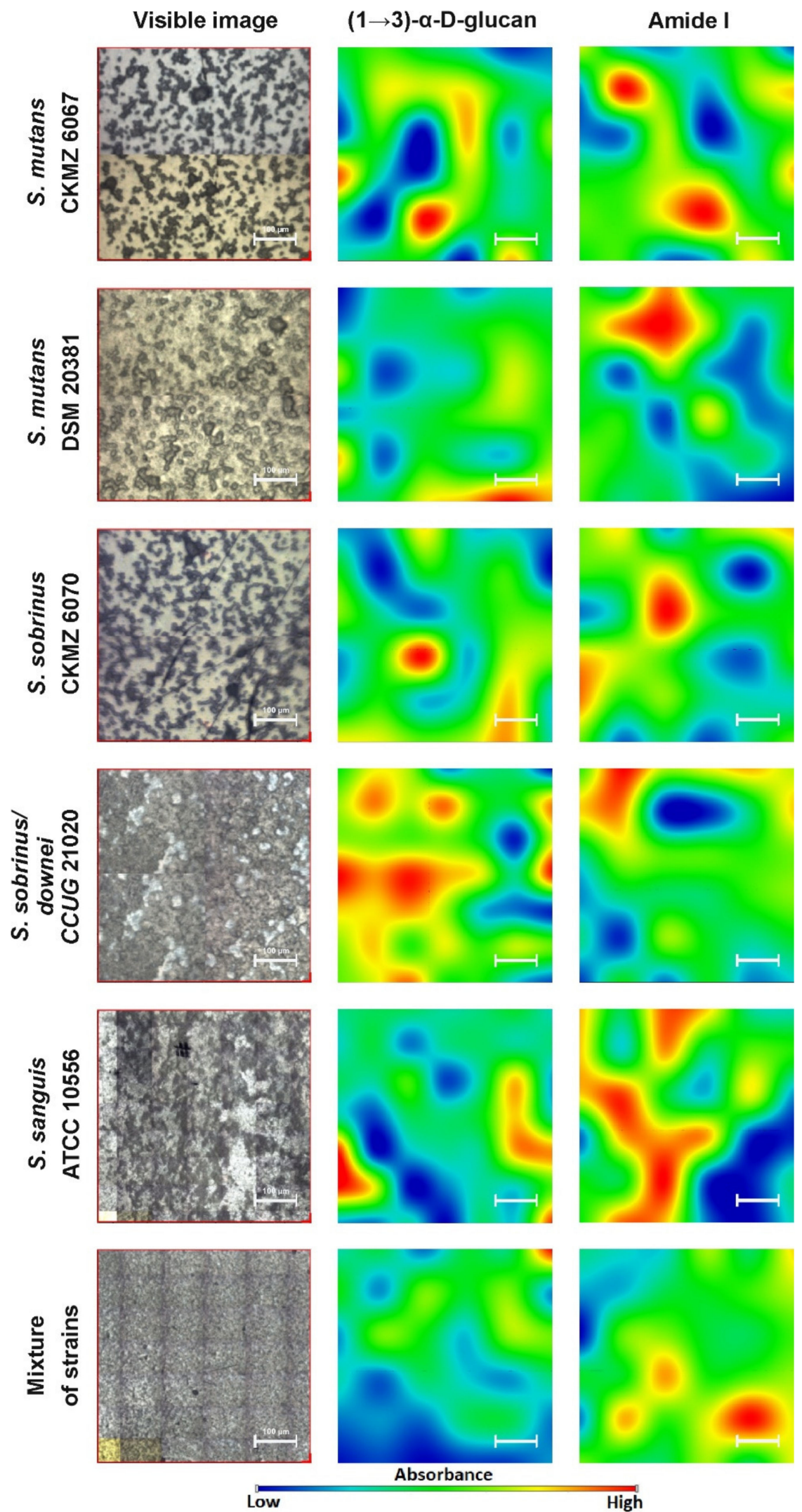

Absorbance

High

Figure 5. The FT-IR chemical maps of compound distributions in bacterial biofilms. The white bar corresponds to $100 \mu \mathrm{m}$. 


\subsection{Raman Spectroscopy}

The relative intensity and Raman spectra normalized to the $1300-1400 \mathrm{~cm}^{-1}$ band (mainly associated with vibrations of the $\mathrm{CH}_{2}$ group present in proteins, but also in lipids [47]) of the bacterial biofilm specimens are depicted in Figures 6 and 7, respectively. A more accurate analysis of the regions of lipids, proteins, and carbohydrates is facilitated by the relative intensity of the Raman spectra presented in Figure 8.

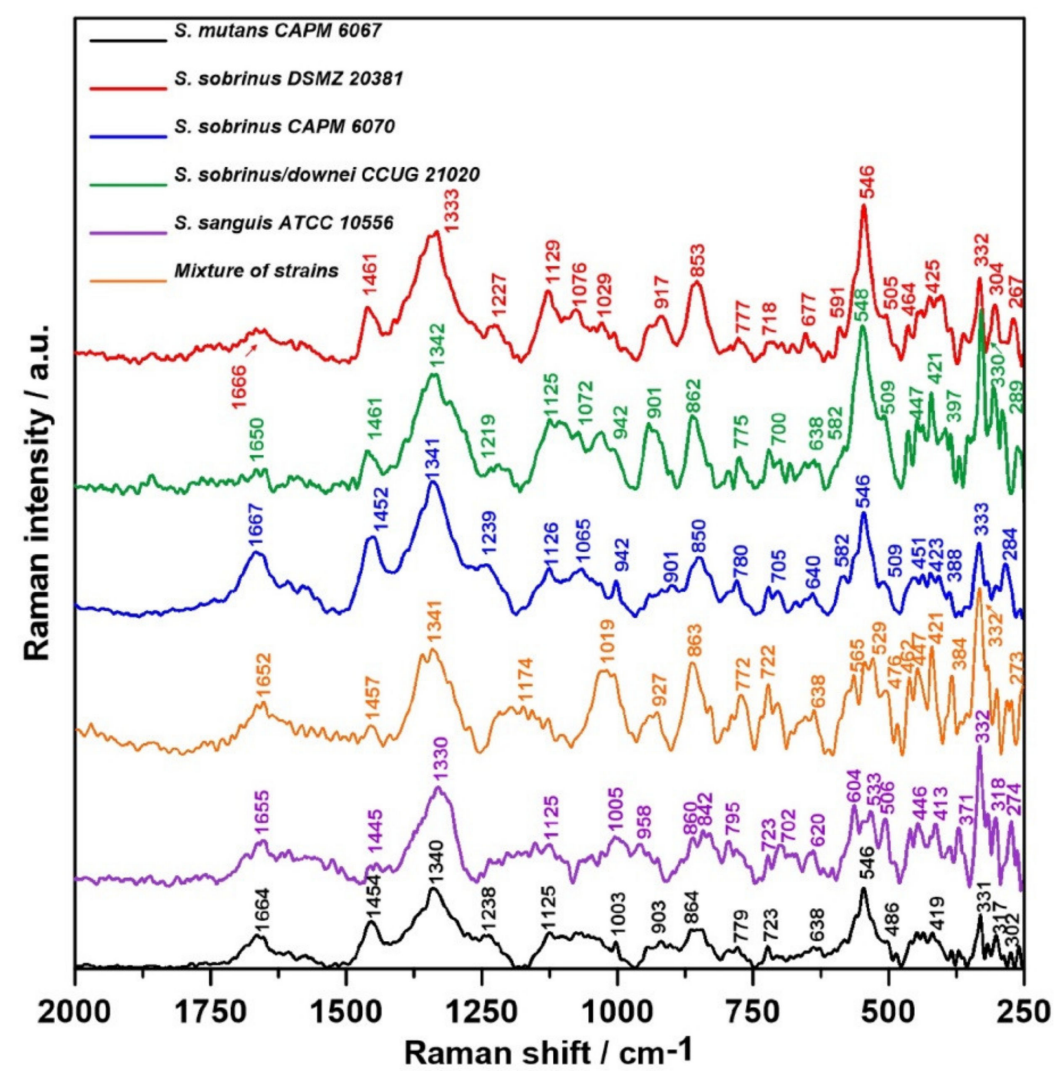

Figure 6. Representative relative intensity of the Raman spectra of bacterial biofilms.

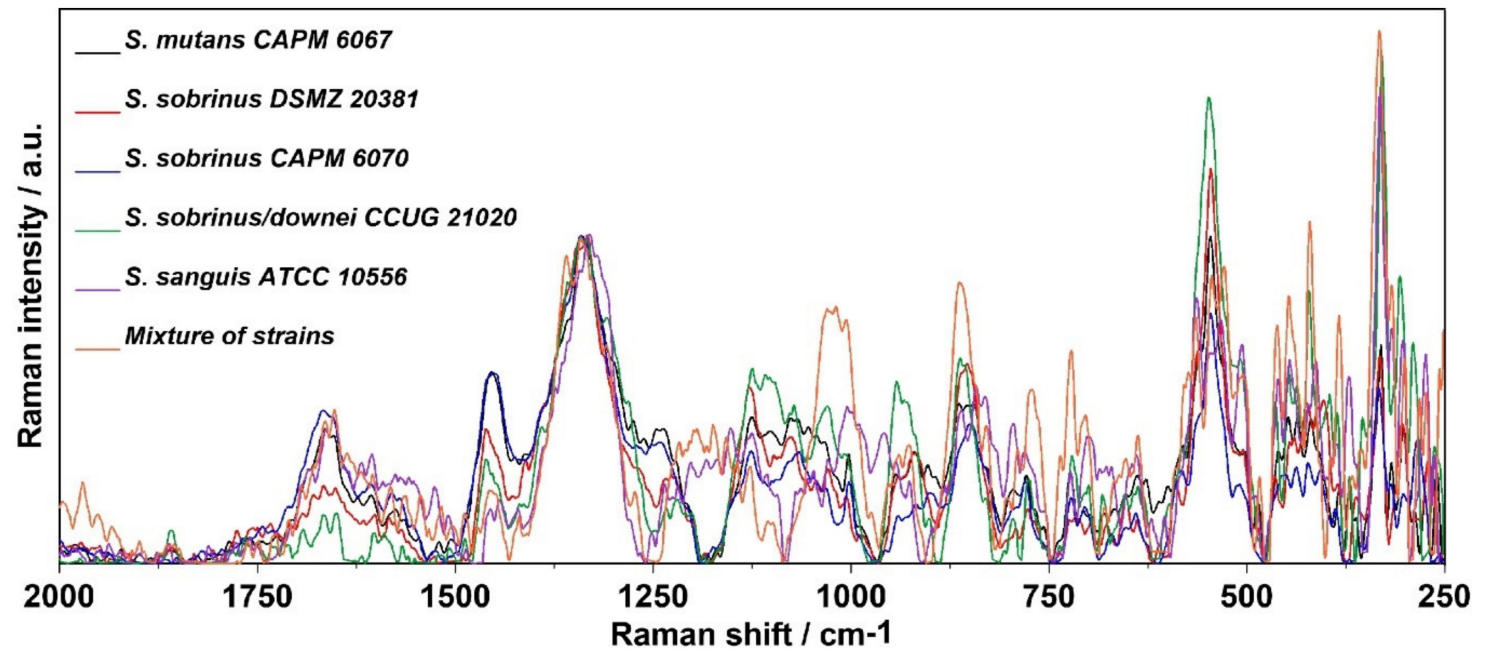

Figure 7. The Raman spectra normalized to the $1300-1400 \mathrm{~cm}^{-1}$ band (assigned to deformation vibration of the $\mathrm{CH}_{2}$ group in lipids and proteins) of bacterial biofilms. 

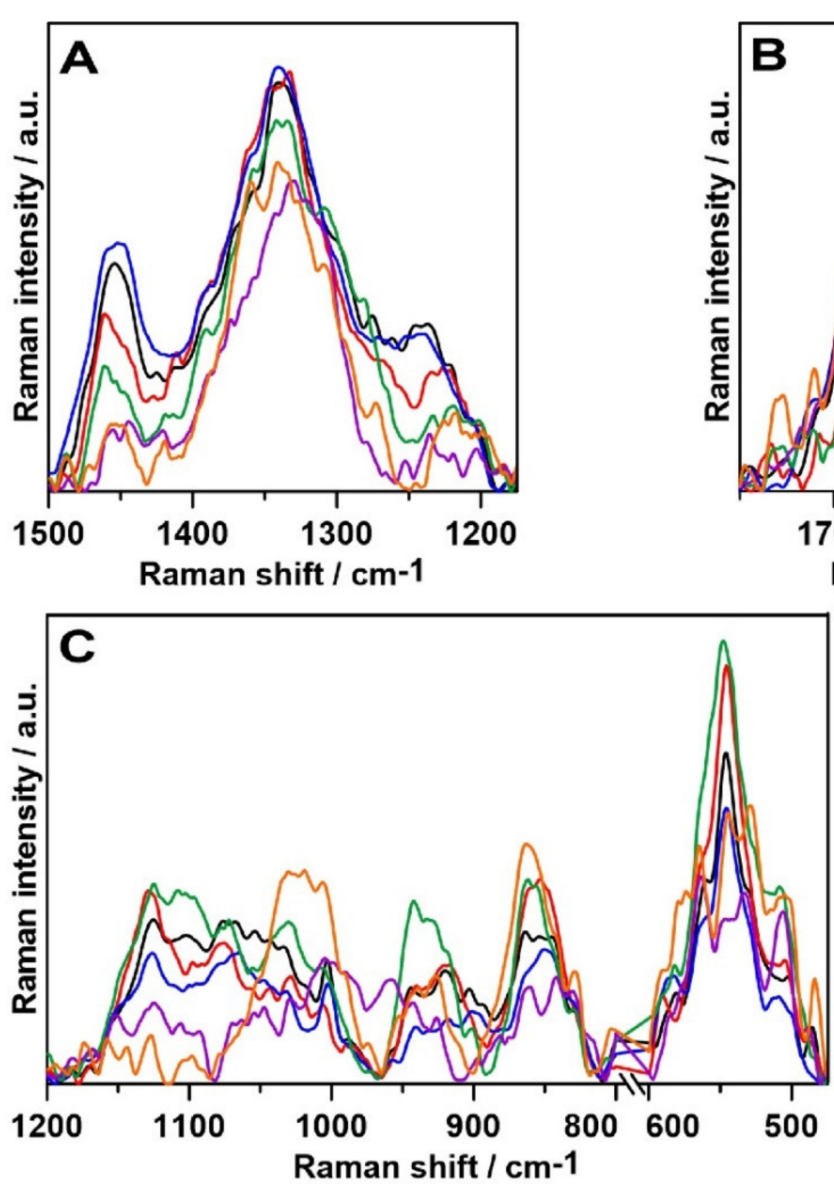

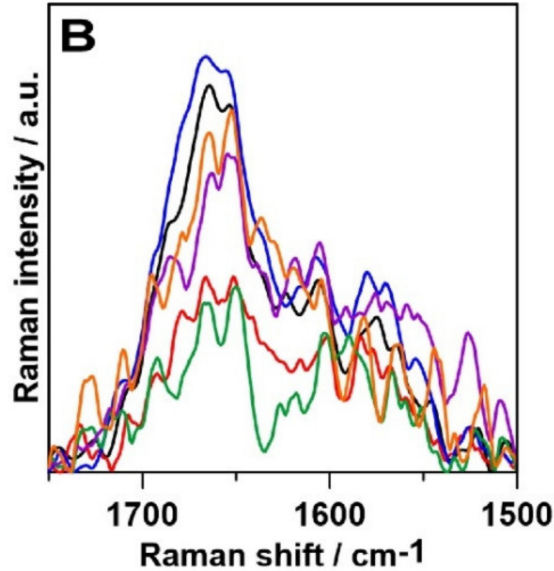

S. mutans CAPM 6067

S. sobrinus DSMZ 20381

S. sobrinus CAPM 6070

S. sobrinus/downei CCUG 21020

S. sanguis ATCC 10556

Mixture of strains

Figure 8. The relative intensity of the Raman spectra of the fingerprint region spectra of: (A) - lipid and Amide III region (1500-1175 cm-1), (B)_Amides I and II region $\left(1750-1500 \mathrm{~cm}^{-1}\right)$, and (C) — carbohydrate region (1200-800 and 610-475 $\left.\mathrm{cm}^{-1}\right)$.

Both in the FT-IR and in Raman spectra (Figures 6 and 7), the main differences were related to the lipid, Amide, and carbohydrate regions. The full information of all of the vibrational modes present in the Raman spectra is collected in Table 2 [47-61]. The Raman spectra of lipids attributed to the presence of the hydrocarbon chain are mainly detected in the three following spectroscopic regions: $1500-1400 \mathrm{~cm}^{-1}, 1300-1250 \mathrm{~cm}^{-1}$, and $1200-1050 \mathrm{~cm}^{-1}$ [48].

The highest intensity of the 1445-1461 $\mathrm{cm}^{-1}$ band assigned to saturated lipids [54] was observed for S. sobrinus CAPM 6070 and S. mutans CAPM 6067, and the lowest for S. sanguis ATCC 1056 (Figure 8A). Differences in the intensity of the previously mentioned band indicate alterations in lipid amounts and compositions of bacterial biofilms during maturation in terms of saturation of lipid fatty acids.

In the spectra of the bacterial biofilms, Amide VI bands could be distinguished (Figure 6). Each of the above bands was observed clearly in all of the biofilm spectra; however, the intensities of the bands varied significantly among them, and the most significant peak was determined as Amide I. The lowest intensity of the Amide I and II bands showed S. sobrinus DSMZ 20381 and S. sobrinus/downei CCUG 21020 (Figure 8B), and that of the Amide III was detected in S. sanguis ATCC 10566 (Figure 8A). The highest intensity of the Amide I and III bands was noted in S. mutans CAPM 6067 and S. sobrinus CAPM 6070 (Figure 8A,B). This may suggest different protein compositions of the biofilms created by the studied strains, and thus other adhesive and caries-forming properties. 
Table 2. The most important bands obtained in the Raman spectra of biofilm samples and the types of vibrations with particular assigned components.

\begin{tabular}{|c|c|}
\hline Raman Shift $\left(\mathrm{cm}^{-1}\right)$ & Assignment and the Type of Vibration * \\
\hline $1700-1600$ & $v(\mathrm{C}=\mathrm{O})$, Amide I \\
\hline $1667-1650$ & $v(\mathrm{C}=\mathrm{C})$, lipids, proteins \\
\hline $1600-1500$ & $v(\mathrm{C}-\mathrm{N}), \delta(\mathrm{N}-\mathrm{H})$, Amide II \\
\hline 1576 & adenine, guanine (DNA bases) \\
\hline 1523 & cytosine (DNA bases) \\
\hline $1500-1400$ & in-plane $\tau$ and out-of-plane $\tau\left(\mathrm{CH}_{2}\right)$, lipids \\
\hline $1461-1445$ & $v_{\mathrm{s}}\left(\mathrm{CH}_{2}\right)$, saturated lipids \\
\hline$\sim 1380$ & $\delta(\mathrm{COH}),(\mathrm{HCO}),(\mathrm{HCC}), v_{\mathrm{s}}(\mathrm{COO}-),(\mathrm{C}-\mathrm{O})$, polyanionic polysaccharide \\
\hline $1340-1330$ & polynucleotide chains, DNA purine bases \\
\hline $1330-1125$ & trans $v(C-C)$, lipids \\
\hline $1300-1250$ & in-plane $\tau$ and out-of-plane $\tau\left(\mathrm{CH}_{3}\right)$, lipids \\
\hline$\sim 1280$ & $\delta(\mathrm{COH}),(\mathrm{HCO}),(\mathrm{HCC}), v_{\mathrm{s}}(\mathrm{COO}-),(\mathrm{C}-\mathrm{O})$, polyanionic polysaccharide \\
\hline $1300-1230$ & $v(\mathrm{C}-\mathrm{N}), \delta(\mathrm{N}-\mathrm{H})$, Amide III \\
\hline 1260 (shoulder band) & $\delta(\mathrm{CH})$, lipids, proteins \\
\hline $1200-1050$ & $v(C-C)$, lipids \\
\hline $1075,1055,980-880$ & combination of rhamnose, galactose, and glucose \\
\hline$\sim 1127$ & $v(\mathrm{C}-\mathrm{N})$, prolinę \\
\hline 1125 & Glucose \\
\hline$\sim 1120$ & $v_{\mathrm{S}}(\mathrm{COC})$, glycosidic bonds \\
\hline$\sim 1094$ & $v_{\text {as }}(\mathrm{COC}),(1 \rightarrow 4)-\beta$-linked glycosidic bonds \\
\hline$\sim 1068$ & trans $\vee(C-C)$, lipids \\
\hline 1000 & phenyloalanine ring breathing \\
\hline $950-790$ & side group $\delta(\mathrm{COH}),(\mathrm{C}-\mathrm{CH}),(\mathrm{O}-\mathrm{CH})$, carbohydrates \\
\hline$\sim 948$ & $(1 \rightarrow 3)$ - $\alpha$-D-glucan \\
\hline $800-640$ & out-of-plane $\tau(\mathrm{N}-\mathrm{H})$, Amide $\mathrm{V}$ \\
\hline 852 & $(1 \rightarrow 6)$ - $\alpha$-D-glucan \\
\hline$\sim 783$ & ring breathing of cytosine, thymine, uracil; $v_{\mathrm{s}}(\mathrm{O}-\mathrm{P}-\mathrm{O})$, phosphodiester bonds in DNA \\
\hline $770-625$ & $\tau(\mathrm{O}=\mathrm{C}-\mathrm{N})$, Amide IV \\
\hline$\sim 757, \sim 520$ & Glucans \\
\hline $600-540$ & out-of-plane $\tau(\mathrm{C}=\mathrm{O})$, Amide VI \\
\hline$\sim 380$ & $\beta$-D-glucoside \\
\hline
\end{tabular}

* Types of vibrations: stretching $(v)$, deformational $(\delta)$, bending $(\tau)$, symmetrical $(s)$, and asymmetrical (as) modes.

The shifting of the wavenumber position of the $(1 \rightarrow 6)-\alpha$-glycosidic bond band $\left(852 \mathrm{~cm}^{-1}\right)$ is associated with the methylesterification degree [59]. The most specific bands for glucans are those centered at $\sim 757$ and $520 \mathrm{~cm}^{-1}$. The $\sim 380 \mathrm{~cm}^{-1}$ band can be ascribed to the $\beta$-D-glucosides (Figure 6). In Gram-positive cells, such as Streptococcus spp., the presence of the bands observed at 880-980, 1055 , and $1075 \mathrm{~cm}^{-1}$ could arise from a combination of the vibrational modes of rhamnose, galactose, and glucose of bacterial cell walls [60]. Other authors report that the specific Raman peaks of glucose are at $1125 \mathrm{~cm}^{-1}[49,61]$. The spectral range $790-950 \mathrm{~cm}^{-1}$ can be assigned to the side-group deformations of biofilm-characteristic carbohydrates [50]. The sugar profile in the area of $475-600 \mathrm{~cm}^{-1}$ for all samples has a similar course (Figure 8C); significant differences occur in the $\sim 1020$ and $\sim 850 \mathrm{~cm}^{-1}$ bands in the mixed-strain specimen and in the $\sim 950 \mathrm{~cm}^{-1}$ band in $S$. sobrinus/downei CCUG 21020, 
where the highest intensity was recorded. These can be interpreted as the differences in glucan and glucose contents.

Other spectral regions are responsible for the occurrence of these three main biofilm components as well. The Raman bands at $\sim 1380$ and $\sim 1280 \mathrm{~cm}^{-1}$ are frequently considered as a polyanionic polysaccharide signature in the bacterial biofilm matrix [51,52]. Moreover, the occurrence of the phenylalanine ring breathing band could be utilized as a protein marker of a biofilm $[47,51]$.

The polysaccharide, protein, and lipid Raman spectral ranges partially overlap with those of the nucleic acids, especially the DNA region.

Subsequently, the second-order derivatives were determined in the three studied spectral regions (Figure 9) attributed to lipids (A), proteins_-precisely, Amides I and II (B) — and polysaccharides (C). Hereby, more information can be drawn regarding the differences in the molecular structures of these components in analyzed bacterial biofilms.
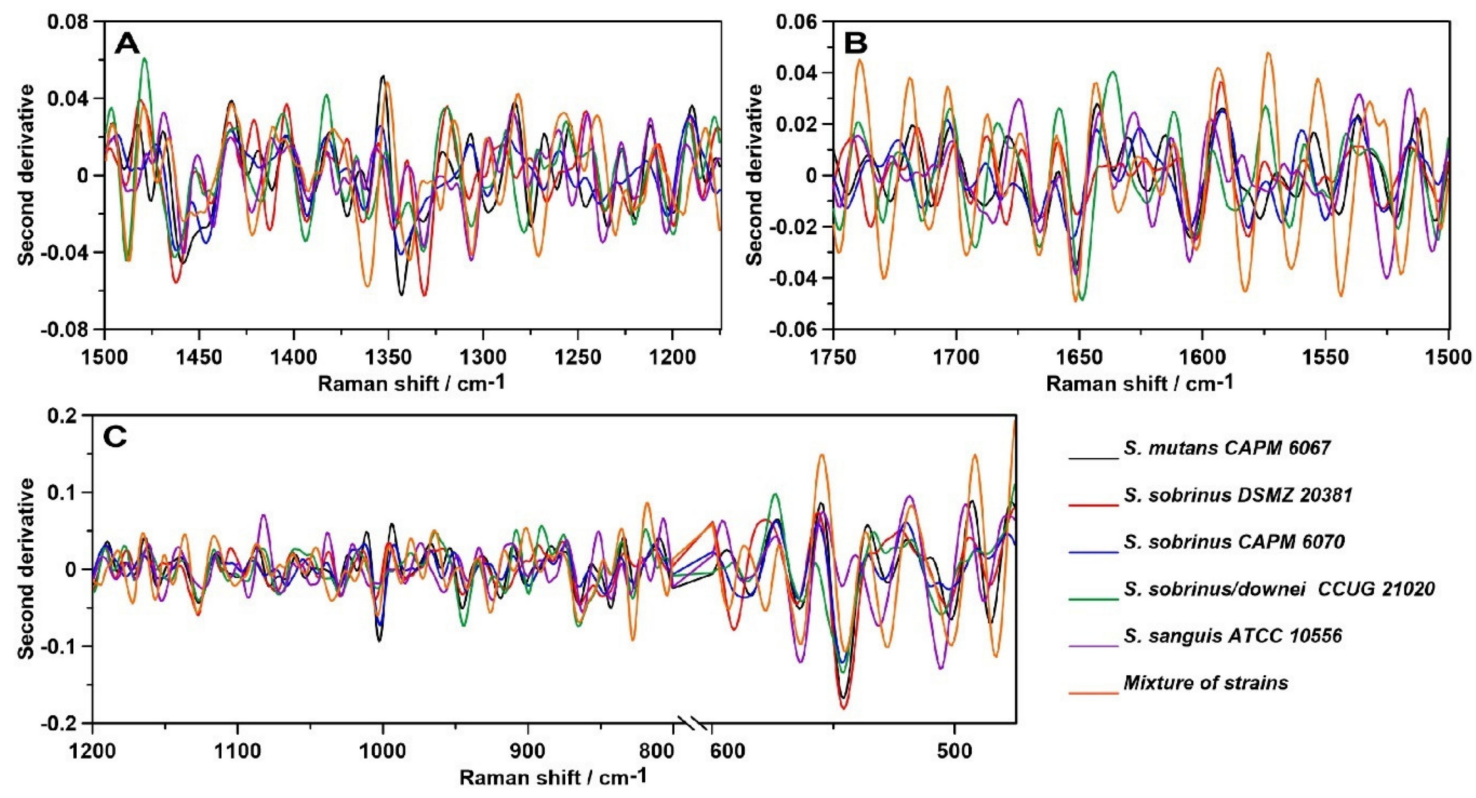

Figure 9. The second-order derivatives of the Raman spectra of biofilms; (A) - lipid region; (B) - protein region; (C)—carbohydrate region.

The second-order derivative of the Raman spectra in the $1500-1175 \mathrm{~cm}^{-1}$ spectral range (Figure 9A) shows considerable differences in the lipid and Amide III profiles of the samples. The most noticeable variation is the $\sim 1350 \mathrm{~cm}^{-1}$ shift, which corresponds to bending vibrations of $-\mathrm{CH}_{2}$ and $-\mathrm{CH}_{3}$ [45]. In addition, the $\sim 1275 \mathrm{~cm}^{-1}$ shift can indicate alterations in the $\alpha$-helical structure of polyprotein chains, and the $\sim 1425 \mathrm{~cm}^{-1}$ shift can be assigned to the $\mathrm{C}-\mathrm{N}$ stretching vibration [62]. The protein-lipid composition of the cell membrane may vary depending on the strain.

In addition, the course of the second derivative determined for the Amide bands significantly differs (Figure 9B). The most similarities can be observed in the mixture of strains and S. sobrinus/downei CCUG 2120. Moreover, in the case of S. sanguis ATCC 10556, additional shifts were detected: 1506, 1525, 1605, and $1620 \mathrm{~cm}^{-1}$, attributed to aggregates and antiparallel $\beta$-sheets in Amide II [63] and Amide I [46], respectively. Among all secondary structures of proteins, the $\beta$-sheet has the greatest diversity of functions. They influence the enzymes, antibodies, transport, or membrane protein functions, and may be crucial for virulence [62].

The course of the second derivative function with respect to sugars (Figure 9C), especially in the $1200-800 \mathrm{~cm}^{-1}$, region indicates similarity in the carbohydrate compositions of the analyzed biofilm samples. The biggest differences, particularly marked in the $600-475 \mathrm{~cm}^{-1}$ range, were detected in the mixture of strains and in the S. sobrinus/downei CCUG 21020 sample. The $527-531 \mathrm{~cm}^{-1}$ and $502-506 \mathrm{~cm}^{-1}$ shifts in these strains are correlated with glucans and D-xylose [64] structures, respectively. 
These data are in accordance with the results presented in Figure 8C, indicating the variant compositions of glucans and other sugars.

\subsection{Raman Imaging}

Similarly to the FT-IR imaging, we performed Raman imaging for the same components, sugars and proteins. The results are presented in Figure 10.

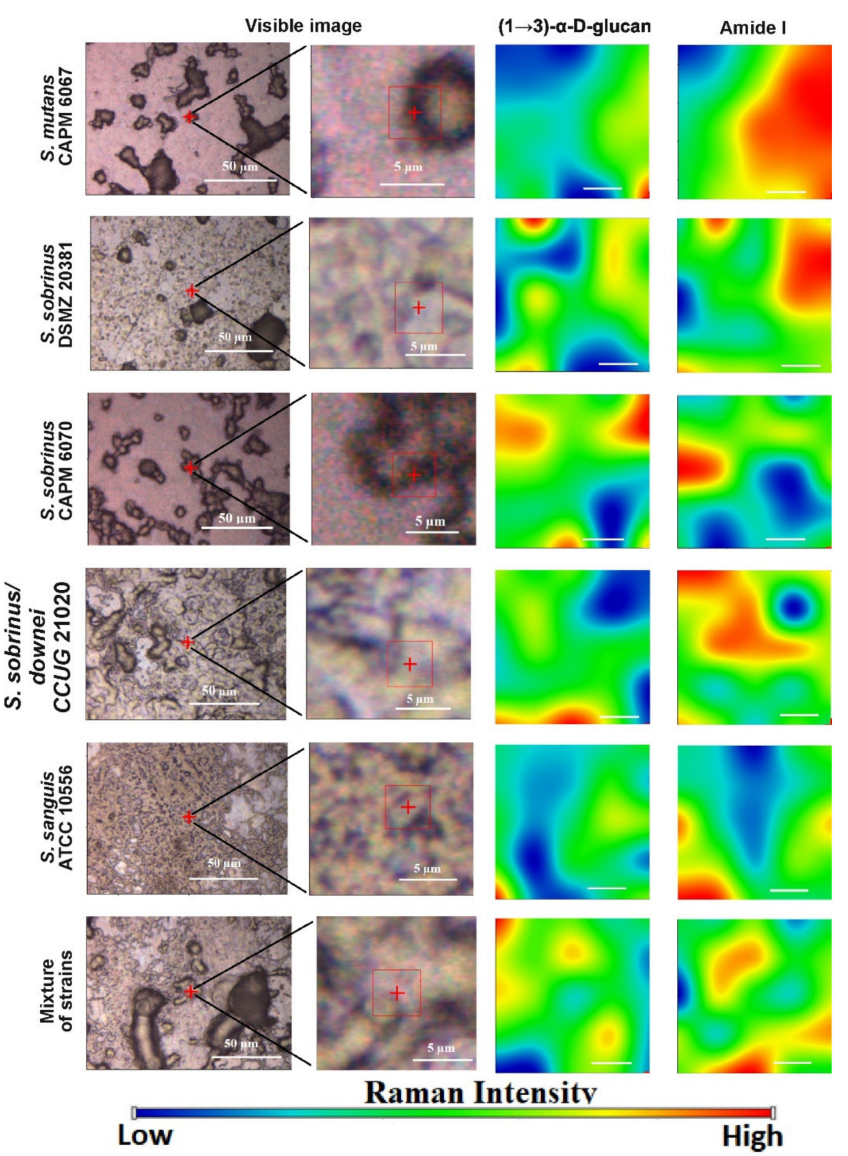

Figure 10. The Raman chemical maps of compound distributions in bacterial biofilms. The red cross and frame in the optical images indicate the mapping area. The white bar in the chemical maps corresponds to $1 \mu \mathrm{m}$.

Identically to FT-IR microspectroscopy, all studied components were present in the Raman imaging visualization. Chemical analysis (Figure 10) confirmed different spatial distributions of $(1 \rightarrow 3)$ - $\alpha$-D-glucan and Amide I in the tested bacterial biofilms. The lowest content of $(1 \rightarrow 3)$ - $\alpha$-D-glucan was detected in the S. sanguis DSMZ 20381 and S. sanguis ATCC 10556 samples. In all biofilm samples formed by the strains selected for study, the content of Amide I was quite high.

Collectively, FT-IR and Raman imaging study proved that less $(1 \rightarrow 3)-\alpha$-D-glucan in bacterial biofilms was formed by the S. mutans CAPM 6067, S. sanguis ATCC 10556, and S. sobrinus/downei CCUG 21020 strains. Furthermore, the amount and distribution of Amide I differs slightly among the probes.

\section{Discussion}

Generally, biofilms are described as "complex communities of bacteria residing within an exopolysaccharide matrix that adheres to a surface" [65]. Biofilm production by bacterial strains is a significant medical and clinical problem because it may be the cause of chronic disease or infections from hospitals, and may be related to infections from implantable medical devices (i.e., dialysis catheters, artificial heart valves, heart Pacemakers, drainage tubes, orthopedic prostheses) [66]. In dentistry, 
biofilms contribute mainly to dental plaque formation, which, in turn, leads to tooth caries and chronic gingivitis. Biofilms also contribute to infection in the para-nasal sinuses and adhere to dental prostheses and implants, constituting a particular risk for patients with impaired immunity [67]. The phenomenon of quorum sensing - the way bacterial cells communicate with each other, determining surface adhesion, EPS, and virulence factor production-is involved in the formation of bacterial biofilms [68]. EPSs are mainly polysaccharides and, in the matrix of the dental plaque, mostly occur as glucose homopolymers, such as $(1 \rightarrow 3)-\alpha-,(1 \rightarrow 4)-\alpha-,(1 \rightarrow 6)-\alpha-D$-glucans, while $(1 \rightarrow 3),(1 \rightarrow 6)-\alpha-D-$ glucan remains crucial for dental caries ethology [2]. The spectral analysis of glucans in biofilms is difficult due to the fact that the presence of these components is attributed to several wavenumbers in both FT-IR and Raman spectra. Furthermore, carbohydrate bands overlap with those of other compounds, such as DNA/RNA, phosphorylated lipids, and proteins [35]. The specificity of glucans can be confirmed by other methods, e.g., polysaccharide-specific monoclonal anti-bodies [69]. FT-IR spectra revealed that a greater amount of $(1 \rightarrow 3),(1 \rightarrow 6)-\alpha$-D-glucan is contained in biofilms formed by S. sobrinus DSMZ 20381 and S. sobrinus CAPM 6070. They also exhibit a similar profile to that of other polysaccharides, and may have a higher caries-forming potential than other tested streptococci strains. Raman spectra confirmed the differences in glucans and xylose content and the lower glucose quantity in S. sobrinus/downei CCUG 21020 and the mixture of strains. The FT-IR and Raman chemical images presented in Figures 5 and 10 show the specific component distribution within the measured area. The distributions of the Amide I and $(1 \rightarrow 3)-\alpha$-D-glucan band vary between the different samples, indicating different cariogenic potential.

So far, it was confirmed that mixed bacterial species' biofilms produce considerably more biomass compared with biofilms of one bacterial species, with no need to provide additional external nutrients $[70,71]$. Moreover, it was stated that these complex bacterial communities have unique properties, e.g., greater resistance to antimicrobial agents and chemical stress/substances, as well as superior expansiveness [70,72]. In our study, the biofilm formed by the mixture of strains has a very similar composition to those of S. mutans CAPM 6067, S. sanguis ATCC 10556, and S. sanguis/downei CCUG 21020 biofilms, while it was characterized by a different polysaccharide content, what can contribute to its different features.

Lipids represent only circa $1.8 \%$ of the biofilm matrix [73], but can lead to binding to metals (e.g., in dental prostheses), enhancing virulence, and increasing microbial adherence together with lipopolysaccharides [74]. It was proven that strongly adherent microbial cells increased the production of saturated membrane lipids [75]. They may also play a role as biosurfactants, like viscosin, surfactant, and emulsan, which enable the bioavailability of dispersed hydrophobic substances [76]. Due to the low content of lipids in bacterial biofilms, we did not study their spatial distribution by FT-IR and Raman microspectroscopies, but we observed that lipid composition varied in the studied strains, especially in the $\sim 2920 \mathrm{~cm}^{-1}$ FT-IR band, influencing the cell membrane saturation. In combination with the sugar composition, it may indicate different adhesion potential. S. mutans CAPM 6067, S. sanguis ATCC 10556, and the mixture of strains had the most similar lipid profile, but also sugar profile, and thus probably have congenial adhesive properties.

Protein in the extracellular matrix mainly has two different functions, depending on the location—as enzymes and virulence factors [77]. Enzymatic proteins are involved in the degradation of water-soluble (proteins, nucleic acids, and polysaccharides) and insoluble (lipids) organic components prevalent in biofilms. They promote cell dispersion and, therefore, colonization of new areas [73]. Virulence agents participate in infection processes, including within the oral cavity [78]. Moreover, it was described that $S$. mutans CAPM 6067 produces glucan-binding proteins, like lectins, leading to formation and stabilization of the matrix [9]. In our research, in terms of protein content, biofilm produced by S. sanguis ATCC 10556 significantly stands out. In the FT-IR spectrum, a higher absorbance intensity was recorded, a different secondary structure of proteins was detected, and a much higher content of Amide I distribution in spectral mapping was found. In the Raman studies, alteration in the $\beta$-sheet secondary structure was also revealed. This may testify for the higher colonization potential of this strain. 
The quantification of various cellular structures like lipids, proteins, and sugars evidences not only the modifications in the metabolism of bacterial cells and bacterial products, but can also serve as a potential marker for cariogenic processes [79]. FT-IR and Raman spectroscopies are very efficient tools applied for the detection, characterization, and analysis of the above-mentioned molecules. These techniques remain an attractive approach because they are cheap and do not require additional reagents, high-grade solvents, or expensive internal standards and equipment. Moreover, they are widely accessible in standard basic laboratories, and these techniques are potent and adequate for routine studies [39].

Although FT-IR and Raman microspectroscopies have been commonly used as potential techniques for analysis of metabolic profiles of cells and their products in biomedical science [80], they have some limitations. Due to their high complexity connected with overlapping or broadened signals from different simultaneously absorbing cellular components, sometimes, it becomes a problem to ascribe variations in absorbance at a particular wavenumber to a specific molecule [35,81]. To overcome this difficulty, advanced mathematical methodologies for spectral data analyses [82,83], such as second-order derivative determination, Gaussian and/or Lorentzian curve fitting, and Voight deconvolution, can be applied [84]. In our case, the second-order derivative function proved to be sufficient because we compared the composition of the biofilms produced by various streptococci strains, not the changes in biofilm created by one bacterial strain during different conditions (such as drug treatment or alternating ion composition, $\mathrm{pH}$, or temperature).

Even though FT-IR and Raman spectroscopies are complementary techniques that measure the vibrational energies of molecules, both methods are based on different selection rules-an absorption process and an inelastic scattering effect of electromagnetic radiation, respectively. Therefore, the combination of these complementary spectroscopies, as we did in this research, can offer a more comprehensive approach for analyzing intact samples, and can ensure more detailed chemical information [13]. The differences in the results obtained using both techniques are due to the different sensitivities to detection of particular chemical groups and types of vibrations; therefore, some overlapping or low-intensity bands can be distinguished only by one of these methods. For instance, by means of Raman spectroscopy, the most intensive bands are recorded from the symmetric, non-polar groups, e.g., $\mathrm{C}-\mathrm{C}, \mathrm{C}=\mathrm{C}, \mathrm{C}-\mathrm{S}$, and S-S, but, generally, vibrational spectroscopies are receptive to the anomeric configuration of glycosidic bonds. Additionally, the Raman scatter from water is relatively weak. [43]. In order to avoid water contribution problems, other techniques should be applied in the study of the biochemical composition of bacterial biofilms, which include, among others, the combination of IR and Raman with confocal scanning light microscopy (CSLM), small-angle $x$-ray scattering (SAXS), surface plasmon resonance imaging (SPRi), electrochemical surface plasmon resonance (EC-SPR), and microscopic approaches: Scanning electron microscopy (SEM) and atomic force microscopy [85].

In summary, our data demonstrate that FT-IR and Raman vibrational spectroscopies coupled with a microscopic approach can be utilized in combination with other biochemical techniques as additional determination and confirmation of the cariogenic potential of bacteria of the genus Streptococcus. The general technique we employed for biochemical analysis is applicable for investigating the bacterial cells' inherence and proliferation, as well as their extracellular polymeric substance (EPS) production. This opens the possibility of applying non-invasive spectral optical techniques to monitor bacterial adhesion and biofilm production directly on tooth enamel, providing a valuable tool for measuring dental pathologies, such as caries, in vivo.

\section{Materials and Methods}

\subsection{Microorganisms}

The streptococcal strains used for this study were: Streptococcus mutans CAPM 6067 and S. sobrinus CAPM 6070 (The Collection of Animal Pathogenic Microorganisms, Brno, Czech Republic), 
S. sobrinus/downei CCUG 21020 (The Culture Collection, University of Göteborg, Gothenburg, Sweden), S. sanguis ATCC 10556 (American Type Culture Collection, Manassas, VA, USA), and S. sobrinus DSMZ 20381 (DSMZ, German Collection of Microorganisms and Cell Cultures, Braunschweig, Germany).

\subsection{Streptococcal Biofilm Formation}

Six $100 \mathrm{~mL}$ flasks, containing $75 \mathrm{~mL}$ brain heart infusion broth (BHI) (BTL, Łódź, Poland) with 2\% $(w / v)$ sucrose, were autoclaved $\left(30 \mathrm{~min}, 121^{\circ} \mathrm{C}\right)$, and then $10^{5} \mathrm{CFU} / \mathrm{mL}$ test bacteria were inoculated into each flask. One flask was inoculated with a mixed culture of all cariogenic streptococci. Subsequently, a sterile aluminum-coated (thickness $\sim 100 \mathrm{~nm}$ ) Clear Borosilicate Float Glass Microscope Slide (DRLI, Deposition Research Lab Inc., St. Charles, MO, USA) was immersed in each flask, and batch cultures were incubated at $37^{\circ} \mathrm{C}$ for $24 \mathrm{~h}$ under stationary conditions. After incubation, media and planktonic cells were removed, and the remaining biofilm adhering to the glass surface was rinsed with phosphate buffered saline (PBS). During the measurements, the samples were semi-dry biofilms.

\subsection{FT-IR Microspectroscopy}

FT-IR spectra were collected in a transflection mode with the use of a Nicolet 6700 FT-IR spectrometer (Thermo Scientific, Waltham, MA, USA) over the range $4000-600 \mathrm{~cm}^{-1}$. For each sample, five spectra under the same conditions were examined and averaged. Each spectrum represented 120 scans taken at a resolution of $4 \mathrm{~cm}^{-1}$ with an optimal signal-to-noise ratio. For a given material, a final spectrum was obtained using OMNIC 8.2.0.387 software (Thermo Fisher Scientific, Madison, WI, USA). Baseline corrections and further processing of spectra were performed using Grams Software and GRAMS/AI software (ThermoGalactic Industries, Keene, NH, USA). In order to trace the qualitative changes in the particular cellular components, such as lipids, proteins, and carbohydrates, the spectral mapping was performed in the appropriate spectral range $\left(3000-2800 \mathrm{~cm}^{-1}\right.$ for lipids, $1700-1470 \mathrm{~cm}^{-1}$ for proteins, $1200-700 \mathrm{~cm}^{-1}$ for sugars) after baseline and offset correction. To determine changes in these structures, second-order derivative spectra were calculated using the Savitzky-Golay algorithm with nine points.

For area mapping, the $X$ and $Y$ step size was $100 \mu \mathrm{m}(4 \times 9$ points). The size of the imaging area of the sample was $400 \times 900 \mu \mathrm{m}$, and the IR objective was $\times 15$. Image assembly was performed using OMNIC 8.2.0.387 and CytoSpec (version 2.00.01, Berlin, Germany) software.

\subsection{Raman Microspectroscopy}

Raman spectra were recorded with the use of a DXR Raman Microscope (Thermo Scientific, Waltham, MA, USA). The excitation laser wavelength was $780 \mathrm{~nm}$ and the output power was set at $13 \mathrm{~mW}$. The spectra were recorded in the $2000-250 \mathrm{~cm}^{-1}$ spectral range with $4 \mathrm{~cm}^{-1}$ of Raman shift resolution. A $25 \mu \mathrm{m}$ pinhole aperture and exposure time of $6 \mathrm{~s}$ with 10 exposures per point with $\times 10$ objective were used. The microscope was equipped with a CCD Camera (Sentech, Ebina, Kanagawa, Japan) and 0.8 mega-pixel CCD sensor. Mapping consisted of 875 single-measure points with a step size of $25 \mu \mathrm{m}$. The autofocus at each map point was used in the case of height-diverted samples. All data processing and image assembly was performed using OMNIC 8.2.0.387 (Thermo Fisher Scientific, Madison, WI, USA) and CytoSpec (version 2.00.01, Berlin, Germany) software. The five spectra from each sample were collected, baseline-corrected, and then averaged before analysis. In the study, the qualitative changes in the same cellular components as in FT-IR spectroscopy for the appropriate Raman fingerprint spectral ranges were chosen: $1500-1175 \mathrm{~cm}^{-1}$ for lipids, $1750-1500 \mathrm{~cm}^{-1}$ for proteins, and $1200-800$ and $610-475 \mathrm{~cm}^{-1}$ for sugars). The spectra were baseline and offset corrected in this bandwidth. To determine changes in these structures, second-order derivative spectra were calculated using the Savitzky-Golay algorithm with thirteen points. 


\section{Conclusions}

FT-IR and Raman spectra of bacterial biofilms provide information on the chemical profile of the sample. Testing does not require prior preparation; moreover, biological material can be tested both dry and wet. Spectroscopic spectra showed that bacterial biofilms consist mainly of a mixture of proteins and polysaccharides. Glucans, as detected during the research, plays an important role in the process of adsorption of pathogens to tooth enamel. This results in an increase in the mass of the bacterial biofilm and better adhesion of the colony to the tooth surface. This, in turn, intensifies carious processes and causes a violation of the enamel structure.

Author Contributions: Conceptualization, A.S.-B. and B.G.; methodology, A.W. and M.P.; formal analysis, B.G.; investigation, M.K. and K.W.; resources, A.S.-B. and M.T.; writing-original draft preparation, B.G.; writing-review and editing, A.S.-B., A.W., B.G., and M.T.; visualization, B.G. and M.K. All authors have read and agreed to the published version of the manuscript.

Funding: This research was funded by Foundation for Polish Science POIR.04.04.00-00-4398/17-00 (B.G., A. S-B) and National Center for Research and Development within the Lider VIII program LIDER/11/0070/L-8/16/NCBR/2017 (M.K., A.S.-B.).

Conflicts of Interest: The authors declare no conflict of interest. The funders had no role in the design of the study, in the collection, analyses, or interpretation of data, in the writing of the manuscript, or in the decision to publish the results.

\section{Abbreviations}

$\begin{array}{ll}\text { FT-IR } & \text { Fourier transform infrared spectroscopy } \\ \text { Gbps } & \text { Glucan-binding proteins } \\ \text { Gtfs } & \text { Glucosyltransferases } \\ \text { PAc } & \text { Cell surface protein antigen c } \\ \text { MS } & \text { Mutans streptococci }\end{array}$

\section{References}

1. Marsh, P.D. Dental diseases-Are these examples of ecological catastrophes? Int. J. Dent. Hyg. 2006, 4 (Suppl. 1), 3-10. [CrossRef]

2. Pleszczyńska, M.; Wiater, A.; Janczarek, M.; Szczodrak, J. (1 $\rightarrow 3)$ - $\alpha$-d-Glucan hydrolases in dental biofilm prevention and control: A review. Int. J. Biol. Macromol. 2015, 79, 761-778. [CrossRef] [PubMed]

3. Loesche, W.J. Role of Streptococcus mutans in human dental decay. Microbiol. Rev. 1986, 50, 353-380. [CrossRef] [PubMed]

4. Aoki, H.; Shiroza, T.; Hayakawa, M.; Sato, S.; Kuramitsu, H.K. Cloning of a streptococcus mutans glucosyltransferase gene coding for insoluble glucan synthesis. Infect. Immun. 1986, 53, 587-594. [CrossRef] [PubMed]

5. Hanada, N.; Kuramitsu, H.K. Isolation and characterization of the Streptococcus mutans gtfD gene, coding for primer-dependent soluble glucan synthesis. Infect. Immun. 1989, 57, 2079-2085. [CrossRef] [PubMed]

6. Hanada, N.; Kuramitsu, H.K. Isolation and characterization of the streptococcus mutans gtfc gene, coding for synthesis of both soluble and insoluble glucans. Infect. Immun. 2005, 56, 1999-2005. [CrossRef]

7. Matsumoto-nakano, M. Role of Streptococcus mutans surface proteins for biofilm formation. Jpn. Dent. Sci. Rev. 2018, 54, 22-29. [CrossRef]

8. Nanbu, A.; Hayakawa, M.; Takada, K.; Shinozaki, N. Production, characterization, and application of monoclonal antibodies which distinguish four glucosyltransferases from Streptococcus sobrinus. FEMS Immunol. Med. Microbiol. 2000, 27, 9-15. [CrossRef]

9. Lynch, D.J.; Fountain, T.L.; Mazurkiewicz, J.E.; Banas, J.A. Glucan-binding proteins are essential for shaping Streptococcus mutans biofilm architecture. FEMS Microbiol. Lett. 2007, 268, 158-165. [CrossRef]

10. Carter, E.A.; Tam, K.K.; Armstrong, R.S.; Lay, P.A. Vibrational spectroscopic mapping and imaging of tissues and cells. Biophys. Rev. 2009, 1, 95-103. [CrossRef]

11. Song, C.L.; Kazarian, S.G. Three-dimensional depth profiling of prostate tissue by micro ATR-FTIR spectroscopic imaging with variable angles of incidence. Analyst 2019, 144, 2954-2964. [CrossRef] [PubMed] 
12. Song, C.L.; Vardaki, M.Z.; Goldin, R.D.; Kazarian, S.G. Fourier transform infrared spectroscopic imaging of colon tissues: Evaluating the significance of amide I and C-H stretching bands in diagnostic applications with machine learning. Anal. Bioanal. Chem. 2019, 411, 6969-6981. [CrossRef] [PubMed]

13. Lin, S.; Li, M.; Cheng, W. FT-IR and Raman vibrational microspectroscopies used for spectral biodiagnosis of human tissues. Spectroscopy 2007, 21, 1-30. [CrossRef]

14. Kazarian, S.G.; Chan, K.L.A. Applications of ATR-FTIR spectroscopic imaging to biomedical samples. Biochim. Biophys. Acta 2006, 1758, 858-867. [CrossRef] [PubMed]

15. Prince, R.C.; Potma, E.O. Going visible: High-resolution coherent Raman imaging of cells and tissues. Light Sci. Appl. 2019, 8, 8-9. [CrossRef]

16. Henry, V.A.; Jessop, J.L.P.; Peeples, T.L. Differentiating Pseudomonas sp. strain ADP cells in suspensions and biofilms using Raman spectroscopy and scanning electron microscopy. Anal. Bioanal. Chem. 2017, 409, 1441-1449. [CrossRef]

17. Ricciardelli, A.; Casillo, A.; Vergara, A.; Balasco, N.; Corsaro, M.M.; Tutino, M.L.; Parrilli, E. Environmental conditions shape the biofilm of the Antarctic bacterium Pseudoalteromonas haloplanktis TAC125. Microbiol. Res. 2019, 218, 66-75. [CrossRef]

18. Imbert, L.; Gourion-Arsiquaud, S.; Villarreal-Ramirez, E.; Spevak, L.; Taleb, H.; van der Meulen, M.C.; Boskey, A.L. Dynamic structure and composition of bone investigated by nanoscale infrared spectroscopy. PLoS ONE 2018, 13, e0202833. [CrossRef]

19. Fu, B.; Sun, X.; Qian, W.; Shen, Y.; Chen, R.; Hannig, M. Evidence of chemical bonding to hydroxyapatite by phosphoric acid esters. Biomaterials 2005, 26, 5104-5110. [CrossRef]

20. Tsuda, H.; Ruben, J.; Arends, J. Raman spectra of human dentin mineral. Eur. J. Oral. Sci. 1996, 104, $123-131$. [CrossRef]

21. Bista, R.K.; Bruch, R.F. Near-infrared spectroscopic studies of self-forming lipids and nanovesicles. In Nanoscale Imaging, Sensing, and Actuation for Biomedical Applications VI; SPIE-International Society for Optics and Photonics: San Francisco, CA, USA, 2009; p. 718809.

22. Liu, Y.; Yao, X.; Liu, Y.W.; Wang, Y. A Fourier transform infrared spectroscopy analysis of carious dentin from transparent zone to normal zone. Caries Res. 2014, 48, 320-329. [CrossRef] [PubMed]

23. Hędzelek, W.; Wachowiak, R.; Marcinkowska, A.; Domka, L. Infrared spectroscopic identification of chosen dental materials and natural teeth. Acta Phys. Pol. A 2008, 114, 471-484. [CrossRef]

24. El-Sharkawyi, Y.H. Detection and characterization of human teeth caries using $2 \mathrm{D}$ correlation raman spectroscopy. J. Biomed. Phys. Eng. 2019, 9, 167-178. [CrossRef] [PubMed]

25. Buchwald, T.; Buchwald, Z. Assessment of the Raman spectroscopy effectiveness in determining the early changes in human enamel caused by artificial caries. Analyst 2019, 144, 1409-1419. [CrossRef] [PubMed]

26. Baiz, C.R.; Reppert, M.; Tokmakoff, A. Amide I two-dimensional infrared spectroscopy: Methods for visualizing the vibrational structure of large proteins. J. Phys. Chem. A 2013, 117, 5955-5961. [CrossRef] [PubMed]

27. Zarnowiec, P. Fourier Transform Infrared Spectroscopy (FTIR) as a tool for the identification and differentiation of pathogenic bacteria. Curr. Med. Chem. 2015, 22, 1710-1718. [CrossRef]

28. Lin, H.; Deng, K.; Zhang, J.; Wang, L.; Zhang, Z.; Luo, Y.; Huang, P. Biochemical detection of fatal hypothermia and hyperthermia in affected rat hypothalamus tissues by Fourier transform infrared spectroscopy. Biosci. Rep. 2019, 39, BSR20181633. [CrossRef]

29. Hernadez, B.; Pfluger, F.; Adenier, A.; Kurglik, S.G.; Ghomi, M. Vibrational analysis of amino acids and short peptides in hydrated media. IV. Amino acids with hydrophobic side chains: L-Alanine, L-Valine, and L-Isoleucine. J. Phys. Chem. 2009, 114, 15319-15330.

30. Gao, Y.; Huo, X.; Dong, L.I.U.; Sun, X.; Sai, H.E.; Wei, G.; Wu, J. Fourier transform infrared microspectroscopy monitoring of 5-fluorouracil-induced apoptosis in SW620 colon cancer cells. Mol. Med. Rep. 2015, 11, 2585-2591. [CrossRef]

31. Choo-Smith, L.P.; Maquelin, K.; Van Vreeswijk, T.; Bruining, H.A.; Puppels, G.J.; Thi, N.N.; Orsini, F. Investigating Microbial (Micro) colony heterogeneity by vibrational spectroscopy. Appl. Environ. Microbiol. 2001, 67, 1461-1469. [CrossRef]

32. Gieroba, B.; Arczewska, M.; Sławińska-Brych, A.; Rzeski, W.; Stepulak, A.; Gagoś, M. Prostate and breast cancer cells death induced by xanthohumol investigated with Fourier transform infrared spectroscopy. Spectrochim. Acta Part A Mol. Biomol. Spectrosc. 2020, 231, 118112. [CrossRef] [PubMed] 
33. Júnior, Z.S.S.; Botta, S.B.; Ana, P.A.; França, C.M.; Fernandes, K.P.S.; Mesquita-Ferrari, R.A.; Bussadori, S.K. Effect of papain-based gel on type I collagen-Spectroscopy applied for microstructural analysis. Sci. Rep. 2015, 5, 11448. [CrossRef] [PubMed]

34. Synytsya, A.; Novák, M. Structural diversity of fungal glucans. Carbohydr. Polym. 2013, 92, 792-809. [CrossRef] [PubMed]

35. Sahu, R.K.; Salman, A.; Mordechai, S. Tracing overlapping biological signals in mid-infrared using colonic tissues as a model system. World J. Gastroenterol. 2017, 23, 286-296. [CrossRef] [PubMed]

36. Yoshida, S.; Miyazaki, M.; Sakai, K.; Takeshita, M.; Yuasa, S.; Sato, A.; Okuyama, H. Fourier transform infrared spectroscopic analysis of rat brain microsomal membranes modified by dietary fatty acids: Possible correlation with altered learning behavior. Biospectroscopy 1997, 3, 281-290. [CrossRef]

37. Baeva, E.; Bleha, R.; Lavrova, E.; Sushytskyi, L.; Čopíková, J.; Jablonsky, I.; Synytsya, A. Polysaccharides from basidiocarps of cultivating mushroom pleurotus ostreatus: Isolation and structural characterization. Molecules 2019, 24, 2740. [CrossRef]

38. Nauman, D.; Helm, D.; Labischinski, H. Microbiological characterizations by FT-IR spectroscopy. Nature 1991, 351, 81-82. [CrossRef]

39. Derenne, A.; Vandersleyen, O.; Goormaghtigh, E. Lipid quantification method using FTIR spectroscopy applied on cancer cell extracts. Biochim. Biophys. Acta Mol. Cell Biol. Lipids 2014, 1841, 1200-1209. [CrossRef]

40. Shapaval, V.; Brandenburg, J.; Blomqvist, J.; Tafintseva, V.; Passoth, V. Biotechnology for Biofuels Biochemical profiling, prediction of total lipid content and fatty acid profile in oleaginous yeasts by FTIR spectroscopy. Biotechnol. Biofuels 2019, 12, 140. [CrossRef]

41. Barth, A. Infrared spectroscopy of proteins. Biochim. Biophys. Acta Bioenerg. 2007, 1767, 1073-1101. [CrossRef]

42. Sabbatini, S.; Conti, C.; Orilisi, G.; Giorgini, E. Infrared spectroscopy as a new tool for studying single living cells: Is there a niche? Biomed. Spectrosc. Imaging 2017, 6, 85-99. [CrossRef]

43. Synytsya, A.; Novak, M. Structural analysis of glucans. Ann. Transl. Med. 2014, 2, 17. [PubMed]

44. Tanaka, S.; Kojić, D.; Tsenkova, R.; Yasui, M. Quantification of anomeric structural changes of glucose solutions using near-infrared spectra. Carbohydr. Res. 2018, 463, 40-46. [CrossRef] [PubMed]

45. Shakeel, F.; Baboota, S.; Ahuja, A.; Ali, J.; Shafiq, S. Skin permeation mechanism and bioavailability enhancement of celecoxib from transdermally applied nanoemulsion. J. Nanobiotechnol. 2008, 6, 1-11. [CrossRef]

46. Kong, J.; Yu, S. Fourier transform infrared spectroscopic analysis of protein secondary structures protein FTIR data analysis and band assign. Acta Biochim. Biophys. Sin. 2007, 39, 549-559. [CrossRef]

47. Huang, H.; Shi, H.; Feng, S.; Chen, W.; Yu, Y.; Lin, D.; Chen, R. Confocal Raman spectroscopic analysis of the cytotoxic response to cisplatin in nasopharyngeal carcinoma cells. Anal. Methods 2013, 5, 260-266. [CrossRef]

48. Czamara, K.; Majzner, K.; Pacia, M.Z.; Kochan, K.; Kaczor, A.; Baranska, M. Raman spectroscopy of lipids: A review. J. Raman Spectrosc. 2015, 46, 4-20. [CrossRef]

49. Rohleder, D.; Kiefer, W.; Petrich, W. Quantitative analysis of serum and serum ultrafiltrate by means of Raman spectroscopy. Analyst 2004, 129, 906-911. [CrossRef]

50. Wagner, M.; Ivleva, N.P.; Haisch, C.; Niessner, R.; Horn, H. Combined use of confocal laser scanning microscopy ( CLSM ) and Raman microscopy (RM): Investigations on EPS-Matrix. Water Res. 2009, 43, 63-76. [CrossRef]

51. Keleştemur, S.; Avci, E.; Çulha, M. Raman and surface-enhanced Raman scattering for biofilm characterization. Chemosensors 2018, 6, 5. [CrossRef]

52. Ivleva, N.P.; Wagner, M.; Horn, H.; Niessner, R.; Haisch, C. Raman microscopy and Surface-Enhanced Raman Scattering (SERS) for in situ analysis of biofilms. J. Biophotonics. 2010, 3, 548-556. [CrossRef] [PubMed]

53. Guo, J.; Cai, W.; Du, B.; Qian, M.; Sun, Z. Raman spectroscopic investigation on the interaction of malignant hepatocytes with doxorubicin. Biophys. Chem. 2009, 140, 57-61. [CrossRef] [PubMed]

54. Verma, S.P.; Wallach, D.F.H. Raman spectra of some saturated, unsaturated and deuterated C18 fatty acids in the hch-deformation and ch-stretching regions. Biochim. Biophys. Acta 1977, 486, 217-227. [CrossRef]

55. Pearman, W.F.; Lawrence-Snyder, M.; Angel, S.M.; Decho, A.W. Surface-enhanced raman spectroscopy for in situ measurements of signaling molecules (autoinducers) relevant to bacteria quorum sensing. Appl. Spectrosc. 2007, 61, 1295-1300. [CrossRef]

56. Schulz, H.; Baranska, M. Identification and quantification of valuable plant substances by IR and Raman spectroscopy. Vib. Spectrosc. 2007, 43, 13-25. [CrossRef] 
57. Szymańska-Chargot, M.; Chylińska, M.; Pieczywek, P.M.; Rösch, P.; Schmitt, M.; Popp, J.; Zdunek, A. Raman imaging of changes in the polysaccharides distribution in the cell wall during apple fruit development and senescence. Planta 2016, 243, 935-945. [CrossRef]

58. Agarwal, U.P. Raman imaging to investigate ultrastructure and composition of plant cell walls: Distribution of lignin and cellulose in black spruce wood (Picea mariana). Planta 2006, 224, 1141-1153. [CrossRef]

59. Synytsya, A. Spectroscopic estimation of feruloyl groups in sugar beet pulp and pectin. Int. Sugar J. 2003, 105, 481-488.

60. Ramirez-Mora, T.; Dávila-Pérez, C.; Torres-Méndez, F.; Valle-Bourrouet, G. Raman spectroscopic characterization of endodontic biofilm matrices. J. Spectrosc. 2019, 2019, 1307397. [CrossRef]

61. Shao, J.; Lin, M.; Li, Y.; Li, X.; Liu, J.; Liang, J.; Yao, H. In vivo blood glucose quantification using raman spectroscopy. PLoS ONE 2012, 7, e48127. [CrossRef]

62. Rygula, A.; Majzner, K.; Marzec, K.M.; Kaczor, A.; Pilarczyk, M.; Baranska, M. Raman spectroscopy of proteins: A review. J. Raman Spectrosc. 2013, 44, 1061-1076. [CrossRef]

63. Srivastava, A.K.; Iconomidou, V.A.; Chryssikos, G.D.; Gionis, V.; Kumar, K.; Hamodrakas, S.J. International Journal of Biological Macromolecules Secondary structure of chorion proteins of the Lepidoptera Pericallia ricini and Ariadne merione by ATR FT-IR and micro-Raman spectroscopy. Int. J. Biol. Macromol. 2011, 49, 317-322. [CrossRef] [PubMed]

64. Gelder, J.; Gussem, K.; Vandenabeele, P.; Moens, L. Reference database of Raman spectra of biological molecules. J. Raman Spectrosc. 2007, 1133-1147. [CrossRef]

65. Khatoon, Z.; Mctiernan, C.D.; Suuronen, E.J.; Mah, T. Bacterial bio fi $\mathrm{lm}$ formation on implantable devices and approaches to its treatment and prevention. Heliyon 2018, 4, e01067. [CrossRef] [PubMed]

66. Jabbouri, S.; Sadovskaya, I. Characteristics of the biofilm matrix and its role as a possible target for the detection and eradication of Staphylococcus epidermidis associated with medical implant infections. FEMS Immunol. Med. Microbiol. 2010, 59, 280-291. [CrossRef]

67. Wroblewska, M.; Struzycka, I.; Mierzwinska-Nastalska, E. Significance of biofilms in dentistry. Przegl. Epidemiol. 2015, 69, 739-744.

68. Nadell, C.D.; Xavier, J.B.; Levin, S.A.; Foster, K.R. The evolution of quorum sensing in bacterial biofilms. PLoS Biol. 2008, 6, 0171-0179. [CrossRef]

69. Mitchell, K.F.; Zarnowski, R.; Sanchez, H.; Edward, J.A.; Reinicke, E.L.; Nett, J.E.; Andes, D.R. Community participation in biofilm matrix assembly and function. Proc. Natl. Acad. Sci. USA 2015, 112, 4092-4097. [CrossRef]

70. Burmølle, M.; Webb, J.S.; Rao, D.; Hansen, L.H.; Sørensen, S.J.; Kjelleberg, S. Enhanced biofilm formation and increased resistance to antimicrobial agents and bacterial invasion are caused by synergistic interactions in multispecies biofilms. Appl. Environ. Microbiol. 2006, 72, 3916-3923. [CrossRef]

71. Ren, D.; Madsen, J.S.; Sørensen, S.J.; Burmølle, M. High prevalence of biofilm synergy among bacterial soil isolates in cocultures indicates bacterial interspecific cooperation. ISME J. 2015, 9, 81-89. [CrossRef]

72. Rice, S.A.; Wuertz, S.; Kjelleberg, S. Next-generation studies of microbial biofilm communities. Microb. Biotechnol. 2016, 9, 677-680. [CrossRef] [PubMed]

73. Flemming, H.C.; Wingender, J. The biofilm matrix. Nat. Rev. Microbiol. 2010, 8, 623-633. [CrossRef] [PubMed]

74. Flemming, H.C.; Neu, T.R.; Wozniak, D.J. The EPS matrix: The "House of Biofilm Cells". J. Bacteriol. 2007, 189, 7945-7947. [CrossRef] [PubMed]

75. Matsuyama, T.; Nakagawa, Y. Surface-active exolipids: Analysis of absolute chemical structures and biological functions. J. Microbiol. Methods 1996, 25, 165-175. [CrossRef]

76. Ward, O.P. Microbial Biosurfactants and Biodegradation. Adv. Exp. Med. Biol. 2010, 672, 65-74. [PubMed]

77. Baughn, A.D.; Rhee, K.Y. Biofilm matix proteins. Microbiol. Spectr. 2014, 2, 201-222.

78. Arciola, R.C.; Campoccia, D.; Speziale, P.; Montanaro, L.; William, J. Biomaterials Bio fi $\operatorname{lm}$ formation in Staphylococcus implant infections. A review of molecular mechanisms and implications for bio fi lm-resistant materials. Biomaterials 2012, 33, 5967-5982. [CrossRef]

79. Nishikawara, F.; Nomura, Y.; Imai, S.; Senda, A.; Hanada, N. Evaluation of cariogenic bacteria. Eur. J. Dent. 2007, 01, 031-039. [CrossRef]

80. Diem, M.; Romeo, M.; Boydston-White, S.; Miljkovic, M.; Matthaus, M. A decade of vibrational micro-spectroscopy of human cells and tissue (1994-2004). Analyst 2004, 129, 880-885. [CrossRef] 
81. Zwielly, A.; Gopas, J.; Brkic, G.; Mordechai, S. Discrimination between drug-resistant and non-resistant human melanoma cell lines by FTIR spectroscopy. Analyst 2009, 134, 294-300. [CrossRef]

82. Guo, W.; Piao, S.; Yang, T.C.; Guo, J.; Iqbal, K. High-resolution power spectral estimation method using deconvolution. IEEE J. Ocean. Eng. 2020, 45, 489-499. [CrossRef]

83. Morhac, M.; Matousek, V. High-resolution boosted deconvolution of spectroscopic data. J. Comput. Appl. Math. 2011, 235, 1629-1640. [CrossRef]

84. Váczi, T. A new, simple approximation for the deconvolution of instrumental broadening in spectroscopic band profiles. Appl. Spectrosc. 2014, 68, 1274-1278. [CrossRef]

85. Wilson, C.; Lukowicz, R.; Merchant, S.; Valquier-Flynn, H.; Caballero, J.; Sandoval, J.; Clement, B. Quantitative and qualitative assessment methods for biofilm growth: A mini-review. Res. Rev. J. Eng. Technol. 2017, 6, 1-8.

(C) 2020 by the authors. Licensee MDPI, Basel, Switzerland. This article is an open access article distributed under the terms and conditions of the Creative Commons Attribution (CC BY) license (http://creativecommons.org/licenses/by/4.0/). 